\title{
《E] EDUMASPUL
}

Vol. 5 - No. 1, year (2021), page 451 - 457

| ISSN 2548-8201 (Print)| 2580-0469) (Online)|

\section{HUBUNGAN PENGETAHUAN SISWA TENTANG HIV DAN AIDSDENGAN STIGMA TERHADAP ODHADI SMAN 5 MAKASSAR}

\author{
Mardhatillah $^{1}$, Devy Febrianti ${ }^{2}$, Zulkarnain Sulaiman ${ }^{3}$, Sunandar Said ${ }^{4}$ \\ ${ }^{1}$ FakultasIlmu Kesehatan, Universitas Muhammadiyah SidenrengRappang, Indonesia. \\ ${ }^{2,3,4}$ Fakultas Ilmu Kesehatan, Universitas Muhammadiyah SidenrengRappang, Indonesia. \\ * Corresponding Author. E-mail: ${ }^{1}$ mardhatillah.ds@gmail.com
}

\begin{tabular}{|l|l|l|}
\hline Receive: 17/12/2020 & Accepted: 16/02/2021 & Published: 09/03/2021
\end{tabular}

\begin{abstract}
Abstrak
HIV merupakan virus penyebab AIDS yang menyerang sistem kekebalan tubuh makhluk hidup. Data profil kesehatan kota Makassar tahun 2020, tercatat penderita HIV dan AIDS sebanyak10.819 kasus. Penelitian ini bertujuan untuk mengetahui hubungan antara pengetahuan dan sikap siswa tentang HIV dan AIDS dengan stigma terhadap ODHA di SMAN 5 Makassar. Jenis penelitian yang digunakan adalah penelitian observasional dengan rancangan cross sectional study. Jumlah sampel dalam penelitian ini yaitu 260 siswa SMAN 5 Makassar. Pengambilan sampel dilakukan dengan menggunakan teknik proportional stratified random sampling. Analisis data dilakukan dengan menggunakan chi square. Hasil penelitian menunjukkan bahwa $p<0,005$ yang berarti ada hubungan antara pengetahuan tentang HIV dan AIDS dengan stigma terhadap ODHA dengan $p=0,020$, ada hubungan antara sikap siswa dengan stigma terhadap ODHA dengan $p=0,001$ dan ada hubungan antara partisipasi siswa pada kegiatan HIV dan AIDS dengan stigma terhadap ODHA dengan nilai $p=0,001$. Kesimpulan dari penelitian ini adalah ada hubungan antara pengetahuan, sikap dan partisipasi siswa tentang HIV dan AIDS dengan stigma terhadap ODHA di SMAN 5 Makassar.
\end{abstract}

Kata Kunci: ODHA, Pengetahuan, Sikap, Siswa, Stigma,

\begin{abstract}
$H I V$ is the virus that leads to AIDS that attacks the immune system of living creatures. According to regency/city health profile data for the year of 2020, there were 10.819cases of HIV andAIDS. This research aims to discover the relationship between the knowledge and behavior of students regarding HIV and AIDS and the social stigma towards ODHA in SMAN5 Makassar. The research conducted is observational with a cross sectionalstudy design. The sample data collected for this study was composed of 260 students of SMAN5 Makassar. Data collection was performed using Proportional Stratified Random Sampling. Data analysis was done by implementing chi square. The results of this research yielded a p-value of less than 0.005. There exists a correlation between the level of HIV/AIDS-related knowledge and the social stigma toward ODHA $(p=0,020)$. There also exists a correlation between student behavior and social stigma toward ODHA $(p=0,001)$. Based on the results of this study, there exists a relationship between knowledge and behavior of students about HIV/AIDS and the stigma toward ODHA in SMAN5 Makassar.
\end{abstract}




\section{Pendahuluan}

Human Immunodeficiency Virus (HIV) merupakan virus yang menyerang sel darah putih yang merusak sistem kekebalan tubuh. Acquired Immuno Deficiency Syndrome (AIDS) yang merupakan dampak dari perkembangbiakan virus HIV dalam tubuh makhluk hidup. Penderita HIV memerlukan pengobatan dengan Antiretroviral (ARV) untuk menurunkan jumlah virus HIV di dalam tubuh agar tidak masuk ke dalam stadium AIDS, sedangkan penderita AIDS membutuhkan pengobatan ARV untuk mencegah terjadinya infeksi oportunistik dengan berbagai komplikasinya[1].

Pada gambar di atas terlihat bahwa populasi terinfeksi HIV terbesar di dunia adalah di benua Afrika (25,7 juta orang), kemudian di Asia Tenggara (3,8 juta), dan di Amerika (3,5 juta). Sedangkan yang terendah ada di Pasifik Barat sebanyak 1,9 juta orang. Tingginya populasi orang terinfeksi HIV di Asia Tenggara mengharuskan Indonesia untuk lebih waspada terhadap penyebaran dan penularan virus ini[1].

data kasus HIV AIDS di Indonesia terus meningkat dari tahun ke tahun. Seperti pada gambar di bawah ini, terlihat bahwa selama sebelas tahun terakhir jumlah kasus HIV di Indonesia mencapai puncaknya pada tahun 2019, yaitu sebanyak 50.282 kasus. Berdasarkan data WHO tahun 2019, terdapat $78 \%$ infeksi HIV baru di regional Asia Pasifik. Untuk kasus AIDS tertinggi selama sebelas tahun terakhir pada tahun 2013, yaitu 12.214 kasus.[1]

lima provinsi dengan jumlah kasus HIV terbanyak adalah Jawa Timur, DKI Jakarta, Jawa Barat, Jawa Tengah, dan Papua, dimana pada tahun 2017 kasus HIV terbanyak juga dimiliki oleh kelima provinsi tersebut. Sedangkan di Gambar 3, diketahui bahwa provinsi dengan jumlah kasus AIDS terbanyak adalah Jawa Tengah, Papua, Jawa Timur, DKI Jakarta, dan Kepulauan Riau. Kasus AIDS di Jawa
Tengah adalah sekitar $22 \%$ dari total kasus di Indonesia. Tren kasus HIV dan AIDS tertinggi dari tahun 2017 sampai dengan 2019 masih sama, yaitu sebagian besar di pulau Jawa[1].

Berdasarkan laporan dari Dinas Kesehatan Provinsi Sulsel tahun 2018, estimasi ODHA sekitar 16.676 orang dan yang ditemukan HIV+ sekitar 8.821 dan yang masuk perawatan 10.879 , memulai ART 5.965 serta yang masih melakukan ART 3.254. Sedangkan untuk testing pada kelompok risiko pada tahun 2018 terlihat masih jauh dari target yang diharapkan terutama pada kelompok LSL, WPS, pasangan risti, dan TB (Jumlah testing pada pasangan Risti 2.994 sedangkan target 57.839; pada penderita TB jumlah testing 9.108, target 68.054; LSL jumlah testing 4.499 dan target 16.594)[2]

Data kasus HIV di Sulawesi tahun 2017 sebanyak1.089kasus. Sedangkankasus AIDS sebanyak220[3]. Dalam sebaran jumlah kasus HIV dan AIDS di Kabupaten/Kota Se-Sulawesi Selatan diperoleh data 8 Kabupaten/Kota tertinggi jumlah kasus HIV/AIDS yaitu Kota Makassar (10.819 kasus), Pare-Pare (561 kasus), Kabuaten Jeneponto (369 kasus), Kota Palopo (298 Kasus), Kabupaten Wajo (203 kasus), Kabupaten Sidrap (198 kasus) dan Kabupaten Bulukumba (178 kasus)[2].

Tingginya kasus HIV dan AIDS ini tentunya tidak lepas dari permasalahan stigma terhadap ODHA yang seringkali menjadi hambatan dalam upaya menurunkan prevalensi HIV dan AIDS. Stigma adalah ciri negatif yang menempel pada pribadi seseorang karena pengaruh lingkungannya. Stigma dengan sendirinya akan melahirkan diskriminasi yang didefinisikan sebagai tindakan yang menghakimi terhadap orang - orang berdasarkan status HIV mereka, baik yang pasti maupun diperkirakan atau keadaan kesehatan mereka[4]

$\begin{array}{lll}\text { Stigma } & \begin{array}{l}\text { menyebabkan } \\ \text { ingin }\end{array} & \begin{array}{l}\text { ODHA tidak } \\ \text { untuk }\end{array}\end{array}$


menolakmendapatkan pelayanan kesehatan serta takut untuk membuka status[5]. Stigma sudah menjadi ketakutan terbesar terhadap ODHA namun dengan pengetahuan yang cukup, hal ini bisa sedikit membantu mengubah pandangan masyarakat.

Data dari kementerian kesehatan Indonesia menunjukkan $75 \%$ warga Indonesia yang berusia antara 15 hingga 49 tahun percaya HIV ditularkan oleh nyamuk. Pengetahuan tentang infeksi menular seksual dapat ditingkatkan dengan pemberian pendidikan kesehatan reproduksi yang dimulai pada usia remaja. Responden dengan pendidikan tinggi cenderung tingkat pengetahuannya lebih baik[6].

Hasil penelitian lain menunjukan bahwa responden pada umumnya belum tahu atau kurang pengetahuan tentang penyakit AIDS dan hanya sedikit yang tingkat pengetahuannya baik tentang AIDS, selain itu sebagian besar responden memperlihatkan sikap yang tidak setuju sehubungan dengan penyakit AIDS dan sisanya memperlihatkan sikap yang setuju tentang penyakit AIDS[7]

seseorang mempunyai pengetahuan baik tentang HIV-AIDS mempunyai kemungkinan berpengaruh mengurangi stigma sebesar 2 kali dibandingkan jika seseorang mempunyai pengetahuan kurang tentang HIV-AIDS. Sebaliknya jika seseorang mempunyai pengetahuan kurang tentang HIV-AIDS maka akan berpengaruh memberikan stigma terhadap ODHA sebesar 2 kali lebih besar dibandingkan dengan mereka yang memiliki pengetahuan baik terhadap ODHA. tetangga yang mempunyai sikap kurang terhadap ODHA mempunyai peluang memberikan stigma terhadap ODHA sebesar 2.014 kali lebih besar dari pada tetangga yang mempunyai sikap baik[8]. Penelitian ini bertujuan untuk mengetahui hubungan antara pengetahuan dan sikap siswa tentang HIV dan AIDS dengan stigma terhadap ODHA di SMAN 5 Makassar.

\section{Metode}

Jenis penelitian yang digunakan adalah penelitian observasional dengan rancangan cross sectional study. Populasi pada penelitian ini adalah seluruh siswa SMA Negeri 5 Makassar yang berjumlah 802 orang. Sampel dalam penelitian ini adalah siswa kelas XI dan XII SMA Negeri 5 Makassar yang masih terdaftar sebagai siswa di SMA Negeri 5 Makassar yang berjumlah 260 orang dan diambil dengan menggunakan teknik pengambilan sampel proporsional stratified random sampling. Teknik analisis yang digunakan adalah analisis univariat dan analisis bivariat dengan uji chi-square. Data primer diperoleh dengan mengambil data dari responden dengan menggunakan kuesioner. Data yang telah diolah sebelumnya, selanjutnya akan dianalisis dengan menggunakan program komputer.

\section{Hasil dan Pembahasan}

Berdasarkan data yang diperoleh menunjukkan bahwa sebagian besar $(31,2 \%)$ responden berasal dari kelas XI IPS dan XII IPA, setengah dari responden berumur 16 tahun. Sebanyak dua per tiga $(64,6 \%)$ dari semua responden berjenis kelamin perempuan, pendidikan terakhir ayah responden sebagian besar $(81,9 \%)$ tamatan perguruan tinggi dan pendidikan terakhir ibu responden setengahnya $(50,8 \%)$ tamatan perguruan tinggi dari 260 responden.

Tabel 1. Distribusi Karakteristik Responden

\begin{tabular}{lcc}
\hline $\begin{array}{c}\text { Karakteristik } \\
\text { Responden }\end{array}$ & $\mathbf{n}$ & $\%$ \\
\hline Kelas & & \\
XI IPA & 49 & 18,8 \\
XI IPS & 81 & 31,2 \\
XII IPA & 81 & 31,2 \\
XII IPS & 49 & 18,8 \\
Umur & & \\
16 tahun & 36 & 13,8 \\
17 tahun & 135 & 51,9 \\
18 tahun & 88 & 33,8 \\
19 tahun & 1 & 0,4 \\
\hline
\end{tabular}




\begin{tabular}{lcc}
\hline Jenis Kelamin & & \\
$\quad$ Laki - laki & 92 & 35,4 \\
$\quad$ Perempuan & 168 & 64,6 \\
$\begin{array}{l}\text { Pendidikan terakhir } \\
\text { ayah }\end{array}$ & \\
$\quad$ Tamat SMP & 2 & 0,8 \\
$\quad$ Tamat SMA & 45 & 17,3 \\
$\quad$ PerguruanTinggi & 213 & 81,9 \\
$\begin{array}{l}\text { Pendidikan terakhir } \\
\text { ibu } \\
\text { Tamat SMP }\end{array}$ & \\
$\quad$ Tamat SMA & 122 & 46,9 \\
Perguruan Tinggi & 132 & 50,8 \\
\hline \multicolumn{2}{c}{ Data menunjukan bahwa lebih dari }
\end{tabular}
dua per tiga $(67,3 \%)$ responden yang memiliki pengetahuan yang cukup dan ada $85(32,7 \%)$ responden dengan pengetahuan yang kurang tentang HIV dan AIDS. Lebihdarisetengah 58,8\%responden yang memilikisikap yang positif, sedangkan $41,2 \%$ yang memilikisikap yang negatifterhadapODHA dan dua per tiga $(69,2 \%)$ responden memiliki partisipasi yang cukup serta ada $30,8 \%$ yang memiliki partisipasi yang kurang pada kegiatan HIV dan AIDS.

Tabel2. Distribusi Pengetahuan, Sikap,

Partisipasi Siswa dan StigmaODHA Tentang HIV dan AIDS

\begin{tabular}{ccc}
\hline $\begin{array}{c}\text { Variabel } \\
\text { Penelitian }\end{array}$ & $\mathbf{n}$ & \% \\
\hline Pengetahuan & & \\
Kurang & 85 & 32,7 \\
Cukup & 175 & 67,3 \\
Sikap & & \\
Negatif & 107 & 41,2 \\
Positif & 153 & 58,8 \\
Partisipasi & & \\
Kurang & 80 & 30,8 \\
Cukup & 180 & 69,2 \\
Stigma ODHA & & \\
Ya & 126 & 48,5 \\
Tidak & 134 & 51,5 \\
\hline
\end{tabular}

\section{Variabel}

pengetahuan menunjukkanbahwasebanyak 143 siswa yang memilikipengetahuan yang cukuptentang HIV dan AIDS, 99 siswa $(56,6 \%)$ diantaranyatidakmempunyai stigma terhadap ODHA. Sedangkan pada siswa yang berpengetahuankurangtentang
HIV dan AIDS sebanyak 117 siswa dan kurangdariseperduanya $(41,2 \%)$ respondendiantaranyatidakmemiliki stigma terhadap ODHA dengan nilai $\mathrm{p}=0,020$. Variabelsikapmenunjukanbahwadari 153 responden yang memilikisikappositif, ada 103 siswadiantaranyaatau $67,3 \%$ yang tidakmemiliki stigma terhadap ODHA. Sedangkansiswa yang memilikisikap yang negatifsebanyak 107 siswa dan ada 31 siswa $(29,0 \%)$ diantaranya yang tidakmemiliki stigma terhadap orang dengan HIV dan AIDS dengan nilai $\mathrm{p}=0,001$

Tabel3. HubunganPengetahuan, SikapsertaPartisipasiSiswa pada Kegiatan HIVdan AIDS dengan Stigma Terhadap ODHA di SMAN 5 Makassar

\begin{tabular}{|c|c|c|c|c|c|}
\hline \multirow{3}{*}{$\begin{array}{l}\text { Variabel } \\
\text { Penelitian }\end{array}$} & \multicolumn{4}{|c|}{ Stigma } & \multirow{3}{*}{$\begin{array}{l}\text { Hasil Uji } \\
\text { Statistik } \\
\end{array}$} \\
\hline & \multicolumn{2}{|c|}{ Ya } & \multicolumn{2}{|c|}{ Tidak } & \\
\hline & $\mathbf{n}$ & $\%$ & $\mathbf{n}$ & $\%$ & \\
\hline \multicolumn{6}{|c|}{ Pengetahuan } \\
\hline Kurang & 50 & 58,8 & 35 & 41,2 & $p=0,020$ \\
\hline Cukup & 76 & 43,4 & 99 & 56,6 & \\
\hline \multicolumn{6}{|l|}{ Sikap } \\
\hline Negatif & 76 & 71,0 & 31 & 29,0 & $p=0,001$ \\
\hline Positif & 50 & 32,7 & 103 & 67,3 & \\
\hline $\begin{array}{l}\text { Partisipasi } \\
\text { siswa }\end{array}$ & & & & & $p=0,001$ \\
\hline Kurang & 52 & 65,0 & 28 & 35,0 & \\
\hline Cukup & 74 & 41,1 & 106 & 58,9 & \\
\hline
\end{tabular}

Pada variabel partisipasi siswa menunjukan bahwa dari 180 responden yang memiliki partisipasi cukup dan ada 106 siswa diantaranya atau 58,9\% yang tidak memiliki stigma terhadap ODHA. Sedangkan siswa yang memiliki partisipasi kurang sebanyak 80 siswa dan ada 28 siswa $(35,0 \%)$ diantaranya yang tidak memiliki stigma terhadap orang dengan HIV dan AIDS dengan nilai $\mathrm{p}=0,001$ (Tabel 3). Hasil analisis uji statisitik tiap variabel yang diperoleh nilai $\mathrm{p}<0,05$, dengan demikian Ho ditolak atau dapat disimpulkan bahwa ada hubungan antara pengetahuan, sikap dan partisipasi siswa pada kegiatan HIV dan AIDS dengan stigma terhadap Orang 
dengan HIV dan AIDS di SMAN 5 Makassar.

Usia remaja merupakan usia yang rentan disertai rasa keingintahuan yang tinggi.. Pendidikan kesehatan reproduksi di kalangan remaja bukan hanya memberikan pengetahuan tentang organ reproduksi, tetapi juga mengenai bahaya akibat pergaulan bebas. Pengetahuan merupakan hasil dari tahu dan terjadi setelah orang melakukan pengindraan terhadap objek tertentu, pengetahuan juga merupakan domain yang sangat penting dalam pembentukan perilaku seseorang. Perilaku secara umum dipengaruhi oleh tingkat pengetahuan seseorang[9]. Masih minimnya informasi tentang HIV dan AIDS yang diperoleh menjadi salah satu faktor kurangnya pengetahuan HIV dan AIDS pada remaja.

Hasil penelitian Shaluhiyah juga menyebutkan bahwa karena kurang diterimanya penderita HIV dan AIDS di tengah - tengah masyarakat serta macam macam stigma yang diberikan masyarakat membuat ODHA tidak terbuka karena lingkungan tidak mau menerima orang dengan penyakit HIV dan AIDS dan stigma yang diberikan masyarakat kepada mereka[10]. Kecendrungan rendahnya pemahaman masyarakat tentang HIV dan AIDS dapat meningkatkan kemungkinan terjadinya stigma[11].

Sikap adalah kondisi mental dan neural yang diperoleh dari pengalaman, yang mengarahkan dan secara dinamis mempengaruhi respon-respon individu terhadap semua objek dan situasi yang terkait. Pembentukan sikap remaja sangat dipengaruhi oleh orangtuanya. Pada umumnya, seseorang cenderung memiliki sikap yang konformis atau searah dengan sikap orang yang dianggapnya penting. Pada penelitian Situmeang menyatakan bahwa sebagian besar responden memperlihatkan sikap yang tidak setuju sehubungan dengan penyakit AIDS dan sisanya memperlihatkan sikap yang setuju tentang penyakit AIDS[12].
Hasil penelitian ini menunjukan bahwa dari 153 responden yang memiliki sikap positif, ada 103 siswa diantaranya atau $67,3 \%$ yang tidak mempunyai stigma terhadap ODHA. Sedangkan siswa yang memiliki sikap yang negatif sebanyak 107 siswa dan ada 31 siswa $(29,0 \%)$ diantaranya yang tidak mempunyai stigma terhadap orang dengan HIV dan AIDS. Total jumlah responden yang memiliki sikap positif dua per tiganya tidak memiliki stigma terhadap ODHA. Hasil analisis uji statisitik yang diperoleh dapat disimpulkan bahwa ada hubungan antara sikap siswa tentang HIV dan AIDS dengan stigma terhadap Orang dengan HIV dan AIDS di SMAN 5 Makassar.Hasil penelitian tersebut sejalan dengan penelitian Situmeangyang menunjukan bahwa masih ada remaja yang memiliki sikap yang kurang baik terhadap ODHA dan ada hubungan antara tingkat pengetahuan dan sikap tentang HIV dan AIDS terhadap ODHA[12]. Berdasarkan teori adaptasi apabila tingkat pengetahuan baik setidaknya dapat mendorong untuk mempunyai sikap dan perilaku yang baik pula.

Partisipasi siswa yang dimaksud adalah keikutsertaan para siswa dalam kegiatan - kegiatan yang berhubungan dengan HIV dan AIDS misalkan keikutsertaan siswa pada kegiatan hari AIDS sedunia. Tindakan yang diskriminatif yang sebelumnya ada seperti pengucilan, tidak mau berjabat tangan atau melakukan kontak langsung dengan ODHA masih ada ditengah - tengah masyarakat, namun menunjukkan banyak perubahan sikap dan perilaku ke arah yang lebih baik. Hal ini, diakibatkan oleh peran serta LSM dan masyarakat yang turut serta membantu pemerintah dalam sosialisasi HIV dan AIDS.

Hasil penelitian ini menunjukan bahwa dari 180 responden yang memiliki partisipasi cukup, ada 106 siswa diantaranya atau $58,9 \%$ yang tidak memiliki stigma terhadap ODHA. Sedangkan siswa yang memiliki partisipasi kurang sebanyak 80 siswa dan ada 28 siswa 
$(35,0 \%)$ diantaranya yang tidak memiliki stigma terhadap orang dengan HIV dan AIDS. Total jumlah responden yang memiliki partisipasi cukup lebih dari seperduanya tidak memiliki stigma terhadap ODHA. Hasil analisis uji statisitik yang

diperolehbahwaadahubunganantarapartisipa si siswa pada kegiatan HIV dan AIDSdengan stigma terhadap Orang dengan HIV dan AIDS di SMAN 5 Makassar.

Pada penelitian Pian menunjukkan bahwa interaksi sosial memberikan pengaruh stigma terhadap ODHA di masyarakat. Interaksi sosial mampu mempengaruhi perubahan persepsi terhadap stigma HIV dan AIDS di masyarakat[13]. Capaian hasil evaluasi yang dilakukan oleh Rianti, dkk, didapatkan adanya peningkatan pengetahuan siswa siswi tentang kesehatan reproduksi remaja, HIV AIDS dan bahaya merokok berdasarkanhasilpre dan post testsetelahdilakukanpenyuluhan[14]. Hal ini sejalan dengan penelitian yang dilakukan oleh Nurherawati mengenai pengaruh pendidikan kesehatan tentang penularan HIV dan AIDS terhadap stigma ODHA menyatakan bahwa ada pengaruh yang signifikan dari pendidikan kesehatan terhadap stigma masyarakat[15].

\section{Simpulan(5\%)}

Penelitian ini menyimpulkan bahwa ada hubungan antara pengetahuan siswa $(\mathrm{p}=0,020)$, sikap siswa $(\mathrm{p}=0,001)$ dan partisipasi siswa pada kegiatan tentang HIV dan AIDS $(p=0,001)$ dengan stigma terhadap orang dengan HIV dan AIDS di SMAN 5 Makassar.

\section{DaftarPustaka}

[1] Kemenkes RI, "Infodatin HIV AIDS," Kesehatan, pp. 1-8, 2020.

[2] D. Darmawansyah et al., "Desentralisasi Pelaksanaan Program Penaggulangan HIV/AIDS di Kota Makassar," J. Manaj. Kesehat. Yayasan RS.Dr. Soetomo, vol. 6, no.
2, p. 237, 2020, doi: 10.29241/jmk.v6i2.537.

[3] P. Kesehatan, "Data Dan Informasi," Kesehatan, 2018.

[4] Rumah Sakit Universitas AIrlangga, Manajemen HIV/AIDS. 2019.

[5] M. G. R. Gabriel, M. Svd, I. N. Mgr, G. Manek, and A. Hospital, "HIV atau Human Immunodeficiency Virus merupakan virus yang melemahkan sistem kekebalan tubuh manusia . AIDS adalah singkatan dari Acquired Immuno Deficiency Syndrome , yang merupakan sekumpulan gejala penyakit yang disebabkan oleh penurunan sistem kekebal," 2019.

[6] Kementrian Kesehatan RI, Pedoman Manajemen Program Pencegahan Penularan HIV dan Sifilis dari Ibu ke Anak. 2015.

[7] A. S. W. Sulkarnaen and S. Ronoatmodjo, "Hubungan Antara Pengetahuan Hiv/Aids Dengan Sikap Penolakan Terhadap Orang Dengan Hiv/Aids (Odha) Pada Masyarakat Indonesia (Analisis Lanjut Survei Demografi Dan Kesehatan Indonesia 2012)," J. Kesehat. Reproduksi, vol. 8, no. 1, pp. 41-52, 2017, doi: 10.22435/kespro.v1i8.5222.41-52.

[8] konstantinus hati, "Stigma Masyarakat Terhadap ODHA di Kota Kupang Provinsi NTT," $J$. promosi Kesehat. Indones., vol. 12, 2017.

[9] F. Kasim, "Dampak Perilaku Seks Berisiko terhadap Kesehatan Reproduksi dan Upaya Penanganannya (Studi tentang Perilaku Seks Berisiko pada Usia Muda di Aceh)," J. Stud. Pemuda, vol. 3, no. 1, pp. 39-48, 2014.

[10] Z. Shaluhiyah, S. B. Musthofa, and B. Widjanarko, "Stigma Masyarakat terhadap Orang dengan HIV / AIDS (Public Stigma to People Living with HIV/AIDS)," J. Kesehat. Masy. Nas., vol. 9, no. 4, pp. 333-339, 2014. 
[11] A. Latifa and S. S. Purwaningsih, "PERAN

MADANI MASYARAKAT

DALAM

MENGURANGI STIGMA DAN DISKRIMINASI TERHADAP PENDERITA HIV \&amp; AIDS," $J$. Kependud. Indones., vol. 6, no. 2, pp. 51-76, 2016.

[12] B. Situmeang, S. Syarif, and R. Mahkota, "Hubungan Pengetahuan HIV/AIDS dengan Stigma terhadap Orang dengan HIV/AIDS di Kalangan Remaja 15-19 Tahun di Indonesia (Analisis Data SDKI Tahun 2012)," J. Epidemiol. Kesehat. Indones., vol. 1, no. 2, pp. 35-43, 2017, doi: 10.7454/epidkes.v1i2.1803.

[13] P. Herawati, "HIV / AIDS MASYARAKAT DENGAN INTERAKSI SOSIAL," UIN syarif Hidayatullah, Jakarta, 2011.

[14] E. Rianti, Pencegahan HIV/AIDS Melalui Penyuluhan Kesehatan Reproduksi dan Pembentukan Kader Kesehatan Remaja, vol. 978-602-53, no. January. 2019.

[15] D. E. Nurherawati, "Pengaruh Pendidikan Kesehatan Tentang Penularan HIV/AIDS Terhadap Stigma Masyarakat Pada ODHA di Dusun Sawahan Nogotirto Gamping Sleman Yogyakarta," Univ. 'Aisyiyah, pp. 1-15, 2019.

\section{Profil Penulis}

Penulis pertama Mardhatillah, S.KM., M.Kes., lahir di Pinrang, 17 Mei 1992. Pendidikan Sarjana di tempuh penulis di Universitas Hasanuddin dengan mengambil Jurusan Epidemiologi, Fakultas Kesehatan Masyarakat tahun 2010. Pada jenjang Magister, penulis melanjutkan pendidikannya di Universitas Hasanuddin pada Program Kesehatan Masyarakattahun 2016. Saat ini penulis tercatat sebagaid osen di Universitas Muhammadiyah Sidenreng Rappang, program studi Administrasi Kesehatan.

Penulis kedua Devy Febrianti, S.KM., M.Kes., lahir di Enrekang, 05 Februari 1992. Pendidikan Sarjanaditempuhpenulis di Universitas Muslim Indonesia dengan mengambil Jurusan Epidemiologi, Fakultas Kesehatan Masyarakattahun 2010. Pada jenjang Magister, penulis melanjutkan pendidikannya di Universitas Hasanuddin pada Program Kesehatan Masyarakattahun 2016. Saat ini penulis tercatat sebagai dosen di Universitas Muhammadiyah Sidenreng Rappang, program studi Administrasi Kesehatan.

PenulisketigaZulkarnainSulaiman,

S.KM., M.Kes., lahir di Baranti, 25 Januari 1991. Pendidikan Sarjana ditempuh penulis di Universitas Muslim Indonesia dengan mengambil Jurusan Administrasi Kebijakan Kesehatan, Fakultas Kesehatan Masyarakattahun 2009. Pada jenjang Magister, penulis melanjutkan pendidikannya di Universitas Hasanuddin pada Program Kesehatan Masyarakat tahun 2015. Saat ini penulis tercatat sebagai dosen di Universitas Muhammadiyah Sidenreng Rappang, program studi Administrasi Kesehatan.

Penulis keempat Sunandar Said, S.Kep.,Ns.,M.Kes., lahir di Sidrap, 25 April 1989. Pendidikan Sarjana ditempuh penulis di Stikes Nani Hasanuddin dengan mengambil Jurusan Keperawatan, Fakultas Keperawatan tahun 2008. Kemudian melanjutkan Program Profesi Ners di Stikes Nani Hasanuddin. Pada jenjang Magister, penulis melanjutkan pendidikannya di Universitas Muslim Indonesia pada Program Kesehatan Masyarakat, jurusan Administrasi Kebijakan Kesehatan tahun 2017. Saat ini penulis tercatat sebagai dosen di Universitas Muhammadiyah Sidenreng Rappang, program studi Administrasi Kesehatan. 